\title{
Skill and Capacity of Women through Social Mobilization: Analysis of Urban Women Self Help Groups in Coimbatore City
}

\author{
Kanagaraj $\mathbf{S}^{\mathbf{1}}$, Priya $\mathbf{V}^{\mathbf{2}}$ \\ ${ }^{1}$ Ph.D. Scholar, ${ }^{2}$ Assistant Professor, Dept. of Social Work, Amrita School of Engineering, Coimbatore, Amrita \\ Vishwa Vidyapeetham, India
}

\begin{abstract}
The study attempts to understand and anlayse the skill and capacity of women through social mobilisation. It is proved that the Self Help Groups (SHGs) played a key role in mobilizing the poor towards developing the habit of saving and avail credit from financial institutions. Social Mobilisation has been adopted as an appropriate approach to mobilise the local communities which is essential to carry out any intervention. The main objective of the study is envisioned to identify the enhancement of skill and capacity of the women through social mobilization. The methodology for the study is Survey research and describes the skills and capacities of the women of Urban SHGs. Multi stage sampling was employed to collect data from 14 SHGs comprising of 156 SHG members. The results revealed that participation of group members in SHGs increase their literacy skills, communication skills, banking skills and vocational skills. Also it is evident that a vast majority of the women $(77.6 \%)$ do not have any vocational skills which indicates there is huge need of training women in vocational as well as entrepreneurship skills to generate income.
\end{abstract}

Keywords: Self-help groups, social mobilisation, skills and capacity of women, urban women

\section{Introduction}

The idea of social mobilization, is bringing together people from all sections of the community to increase awareness and plea for specific development programme and support the community for sustainability and selfreliant ${ }^{(1)}$. It can be categorized as community development approach which involves the people actively to address basic reasons of mal development. In the process it gives opportunity to fight for their rights and increase their potential to mobilise resources, network and connect for their betterment ${ }^{(2)}$. There are number of studies how social mobilization influences women empowerment. (3,4) Particularly on how the self-help groups(SHGs) for women living in urban slums can be an effective tool for

\footnotetext{
Corresponding author:

Kanagaraj S

Ph. D Scholar at the Department of Social Work, Amrita Vishwa Vidyapeetham, Coimbatore, India; Email id: kanagarajpublications@gmail.com, Mobile Number: +91 9943703604
}

social mobilization and eventual empowerment. SHGs main purpose is to enable economic empowerment by imparting skill development to gain power and improve their personality to tackle challenges in life ${ }^{(5)}$

Moreover, women need to avail credit facilities, making avenues for political participations; equal educational opportunities alone would not automatically empower them but they play a major role in women empowerment $^{(6)}$. SHGs alone will not be the solution to women empowerment, additionally the secondary level SHGs Federations ensures the sustainability of the $\mathrm{SHGs}^{(7)}$. In certain cases, it is proved that the financial stability has a key role in economic development which results in social well-being. Moreover, there is no single way or panaceas to empower women; it is a different facet which necessitates a variety of approaches for empowering women ${ }^{(8)}$. Empowerment of women and poverty alleviation is generally facilitated by various institutions such as bank, SHGs and $\mathrm{NGOs}^{(9)}$. When income inequality becomes more pronounced it creates adverse effects on physical and mental health. Inequality creates an adverse view on one's health and 
creates deterioration in mental health ${ }^{(10)}$. SHGs are predominantly considered as agencies of empowerment of weaker sections especially women in India; it helps improve livelihood and resolve various health issues ${ }^{(11)}$ (12).

In most cases, it is proved that the SHGs played a key role in mobilizing the poor towards developing the habit of saving and avail credit from financial institutions ${ }^{(4)}$. Also in the recent few decades SHGs promote social mobilization and social accountability aimed to improve the health and nutrition ${ }^{(13)}$. Social Mobilisation has been adopted as an appropriate approach to mobilise the local communities which is essential to carry out any intervention ${ }^{(14)}$. There are strong evidences on SHGs having positive effects on social, economic and political empowerment ${ }^{(15)(16)}$. Though there is a visible way forward for women empowerment we still have a long way to head towards empowerment. Women are a part of the society and they play a significant role in determining the future of the nation ${ }^{(17)}$. The sustainability of the group is prime concern among stake holders of organizing $\mathrm{SHG}^{(18)}$. Moreover the federations of SHGs promotes sustainability and resolves issues in terms of financial provisions ${ }^{(19)}$.

Social mobilisation has to provide a platform for open dialogue, conduct negotiation and reach a consensus on the means of action for sustained living and self-reliance. It deals with probing the felt needs of the community, addressing the real issues than focusing on a slice of reality. This study is an attempt to understand the improvement in skill and capacity of women; resulting in a specific process of change while at the same time resulting in acquisition of material benefits ${ }^{(1)}$.

\section{Objective}

The research is envisioned to identify the enhancement of skill and capacity of the women through social mobilisation. The results of the process of social change consequential to social mobilization in terms of residence, occupation, roles and capacities has also been identified.

\section{Method}

The present research is carried out by Survey research method and describes the skills and capacities of the women of Urban SHGs. The primary data is collected through field survey from Women Self-help groups of Coimbatore urban limit. Multi stage sampling was employed to identify the SHGs that met the objectives of the research. The process of multi stage sampling was carried out by dividing Coimbatore city into 5 zones namely East, West, South, North and Central. In the next stage, SHGs were classified into three stages based on the number of years such as young, middle and old groups and SHGs were selected proportionately representing each zone which resulted in 14 SHGs.

\section{Findings}

The study aims to understand the skill and capacity of women through social mobilization. The data was collected between May 2019 and October 2019 from 14 SHGs comprising of 156 SHG members. The findings of the study reveals that more than half $(60.9 \%)$ of the respondents' are from single families while one fourth $(25.6 \%)$ of the are from Nuclear family and $13.5 \%$ are joint family. The dwindling rates of joint family system is indicative of the characteristic of the urban areas. $78.8 \%$ of the respondents are from Backward class, $14.7 \%$ belong to the Scheduled caste whereas $5.8 \%$ of the respondents are from the most backward class and only $0.6 \%$ belong to other castes. More than half $(58.3 \%)$ of the respondents have their own house and $41.7 \%$ respondents live in rented houses. A good majority, i.e., $89.1 \%$ of the respondents 'are residents of Coimbatore city, $5.8 \%$ of the respondents live within the limits of Coimbatore district, $3.8 \%$ of the respondents are from other district in Tamil Nadu and only $1.3 \%$ of the respondents are from other state. Nearly three fourth (74.4\%) of the respondents live in Semi Pucca house [Semi Pucca refers to a house which is roofed with tiles or Asbestos sheet], 7.7\% of the respondents live in Kutcha house [Kutcha house means hut, damaged house with improper roofing, tent, tin roofing etc.,] and 17.9\% of the respondents live in Pucca house [Pucca refers to a modest concrete roofed house]. Majority of the (83.3\%) respondents are Hindus, $12.2 \%$ are Christians and only $4.5 \%$ are Muslims. Most of the SHGs have people belonging to different religion in their group.

\section{Discussion}

Several studies have proved that the SHGs have the potential that goes past not merely access to credit but various other avenues to improve their skills in terms of literacy, communications skills, banking skills and vocational skills. The SHG approach promotes conditions to improve the status of women as group ${ }^{(20)}$. 
Skills and capacity of women:

Majority of the women (73\%) are highly literate (Reading and writing Skills) and 27\% of the respondents are literate (signature only) and only $1 \%$ is illiterate. As the women get opportunity to become literate after joining Self Help Groups, a good percentage of women become literate after joining SHGs while very less percentage of women do not try to improve their writing and reading skills because the feel that they have aged and it is not required now. Communication skills have been classified based on their ability to meet government officials, political leaders and to speak in public meetings to express your views and opinions. The study revealed that $60.9 \%$ respondents have high communication skills, $32.7 \%$ have poor communication skills and $2.6 \%$ of the respondents have moderate communication skills and only $3.8 \%$ of respondents do not have any communication skills. In the modern era the banking skills are very important, the banking skills has been classified as

Table 1: Skills and capacity of SHG members ability to open an account in a bank/post office, deposit money, withdraw money and borrow loan from bank. The study revealed that $73.1 \%$ of the respondents have high banking skills, $1.9 \%$ respondents have moderate banking skills, $2.6 \%$ of the respondents have low banking skills and only $22.4 \%$ of the respondents do not have any banking skills. Vocational skills are essential for income generation which is a major responsibility of the mobilization process. In this study woman having any one kind of vocational skill has been categorized as having vocational skills and those who have no skills as no vocational skills. In this study majority of the women were skilled in Tailoring, while a meager percent was skilled in toy making and beautician. The study shows that $77.6 \%$ of the respondents do not have any vocational skills and only $22.4 \%$ of the respondents have vocational skills.

Table number 1 shows the detailed frequency and percentage of the respondent's skills and capacity of SHG members.

\begin{tabular}{|l|l|l|l|}
\hline S.No & Contents & Frequency & Percentage \\
\hline i) Literacy & Illiterate & & \\
\hline 1 & Literate & 2 & 1 \\
\hline 2 & Highly literate & 40 & 26 \\
\hline 3 & Total & 114 & 73 \\
\hline & No Communication skills & 156 & 100.0 \\
\hline ii) Communication Skills & & \\
\hline 1 & Poor Communication skills & 6 & 3.8 \\
\hline 2 & Moderate communication skills & 51 & 32.7 \\
\hline 3 & High communication skills & 4 & 2.6 \\
\hline 4 & Total & 95 & 60.9 \\
\hline & No banking Skills & 156 & 100.0 \\
\hline iii) Banking Skills & & \\
\hline 1 & Low Banking Skills & 35 & 22.4 \\
\hline 2 & Moderate Banking Skills & 4 & 2.6 \\
\hline 3 & High Banking Skills & 3 & 1.9 \\
\hline 4 & Total & 114 & 73.1 \\
\hline
\end{tabular}


The table number 2 shows the association between ownership of house, poverty status and type of house of the respondents. There is a significant relationship between the ownership of the house and the type of house that they live in. The table conveys that majority of the respondents live in semi pucca houses. $94.5 \%$ of the respondents who own their house live in Semi pucca and pucca houses. There is significant association between poverty status and the type of house in which they live. $78 \%$ of the respondents living below poverty line live in semi pucca houses. This indicates that in spite of the respondent's habit of saving money and depositing it monthly or weekly, they still find it difficult to build a good habitable house. The money that they save might be from the income of their husband or children. The women who go to work also have been employed in low paid jobs and jobs which are not stable. In addition to the savings habit the women need to be trained in various income generating activities which will enable them to come out of the poverty cycle and eventually improve their standard of living.

Table 2: Association between Ownership of House, Poverty status and the type of house they reside

\begin{tabular}{|c|c|c|c|c|c|c|}
\hline \multirow{2}{*}{ S. No } & \multirow{2}{*}{ Ownership of house } & \multicolumn{3}{|c|}{ Type of house } & \multirow{2}{*}{ Total } & \multirow{2}{*}{$\begin{array}{l}\text { Significance } \\
\text { X2 }\end{array}$} \\
\hline & & Kutcha & Semi Pucca & Pucca & & \\
\hline 1 & Owned & 5 & 62 & 24 & 91 & 11.147 \\
\hline \multirow[t]{3}{*}{2} & Rented & 7 & 54 & 4 & 65 & $\mathrm{Df}=2$ \\
\hline & Total & 12 & 116 & 28 & 156 & $\mathrm{P}=.004$ \\
\hline & Poverty status & & & & & \\
\hline 1 & Below Poverty Line & 12 & 111 & 19 & 142 & 22.671 \\
\hline \multirow[t]{2}{*}{2} & Above Poverty Line & 0 & 5 & 9 & 14 & $\mathrm{Df}=2$ \\
\hline & Total & 12 & 116 & 28 & 156 & $\mathrm{P}=.000$ \\
\hline
\end{tabular}

The table number 3 shows that there is no association between poverty status and their vocational skills. Though a majority of the poor have skills in vocational trade, the individuals are not willing to pursue their goals. The individualistic principle advocates that the interests of the individual have to achieve precedence over the state. Hence the individuals though belonging to a particular self-help group has to be ruled by a set of self-driven goals. This may be a reason for the lack of economic growth among poor, in spite of being trained in vocational skills ${ }^{(10)}$. Also merely vocational skills training would not help to improve the livelihood but in addition it should earn income through vocational skills. Most of the women SHG members have tailoring skills which is not sufficient to earn livelihood. This indicates that SHG members are required to be given viable business entrepreneurship skills through which they can improve their livelihood. There are several opportunities for vocational training but still women choose tailoring as an option for vocational training, which has very less potential to generate income; unless they start a garments unit to scale their business. 
Table 3: Association between Poverty status and their vocational skills

\begin{tabular}{|l|l|l|l|l|l|}
\hline \multirow{2}{*}{ S.No } & \multirow{2}{*}{ Poverty status } & \multicolumn{2}{|l|}{ Vocational Skills } & \multirow{2}{*}{ Total } & \multicolumn{2}{l}{ Significance } \\
\cline { 3 - 6 } & & \multicolumn{2}{|l|}{$\begin{array}{l}\text { Having } \\
\text { vocational skills }\end{array}$} & No vocational skills & \\
\hline 1 & Below Poverty Line & 30 & 112 & 142 & 1.558 \\
\hline 2 & Above Poverty Line & 5 & 9 & 14 & $\mathrm{Df}=1$ \\
\hline & Total & 35 & 121 & 156 & $\mathrm{P}=.212^{*}$ \\
\hline
\end{tabular}

*Not Significant

\section{Conclusion}

The present study suggests that the participation of group members in SHGs increase their literacy skills, communication skills, banking skills and vocational skills. The process of group meeting, attending various awareness training programmes increases their confidence in communication skills. The banking skills are indispensable to every member in the SHG to claim financial benefits from the Banks; financial transactions by group members deliver greater chances of acquiring the banking skills. Vocational skills play a vital role in improving the livelihood of women. From the study it is evident that a vast majority of the women $(77.6 \%)$ do not have any vocational skills which indicates there is huge need of training women in vocational as well as entrepreneurship skills to generate income and improve their material conditions of living.

Conflict of Interest: The authors declare that they have no conflict of interest to disclose.

Source of Funding. The authors have no funding for this study.

Ethical clearance: Ethical Clearance obtained from the Human Ethics Committee.

\section{Reference}

1. Prasad. Social Mobilization: Concept, Meaning and Approach (Part-1). Kurukshetra [Internet]. 2003 [cited 2019 Apr 21];51, No.8:4-11. Available from: http://yojana.gov.in/cms/ (S(paqndwji112anlz4zqswyt3w))/pdf/Kurukshetra/ English/2003/JUN_VOL51_NO 8.pdf
2. Schuftan C. The community development dilemma: What is really empowering? Community Dev J. 1996;31(3):260-4.

3. Veena P. Social Mobilization and Micro-credit for Women's Empowerment: A Study of the DHAN Foundation. In: Burra N, Deshmukh-Ranadive J, Murthy RK, editors. Micro-Credit, Poverty and Empowerment: Linking the Triad. First edit. Sage Publications India Pvt Ltd; 2005. p. 161-99.

4. Reji EM. Social mobilisation, Savings habit and access to credit for the poor through SHGs in Odisha. 2012 [cited 2019 Apr 15]; Available from: http://www.nirdprojms.in/index.php/jrd/article/ viewFile/93392/69216

5. Jose S, Nair L V. Women SHGs in coastal Kerala: The lope side of social development? [Internet]. Vol. 3, International Journal of Sociology and Anthropology. 2011 [cited 2019 May 10]. Available from: http://www.academicjournals.org/ app/webroot/article/article1379494923_Jose and Nair.pdf

6. Kabeer N. The Conditions and Consequences of Choice: Reflections on the Measurement of Women's Empowerment [Internet]. 1999 [cited 2019 May 10]. Available from: http://www. unrisd.org/80256B3C005BCCF9/ (httpAuxPages)/ 31EEF181BEC398A380256 B67005B720A/ \$file/ dp108.pdf

7. Kalpana K. Shifting Trajectories in Microfinance Discourse. Econ Polit Wkly Spec Artic [Internet]. 2005 [cited 2019 May 10];5400-9. Available from: https://www.epw.in/system/files/pdf/2005_40/51/ 
Shifting_Trajectories_in_Microfinance_Discourse. pdf

8. Kabeer N. Is Microfinance a 'Magic Bullet' for Women's Empowerment? Analysis of Findings from South Asia. Econ Polit Wkly [Internet]. 2005 [cited 2019 May 10];4709-18. Available from: https://www.microfinancegateway.org/sites/ default/files/mfg-en-paper-is-microfinance-amagic-bullet-for-womens-empowerment-analysisof-findings-from-south-asia-oct-2005_0.pdf

9. Kalpana K. The Vulnerability of "Self-Help": Women and Microfinance in South India [Internet]. 2008 [cited 2019 May 10]. Available from: http:// www.findevgateway.org/sites/default/files/mfg-enpaper-the-vulnerability-of-self-help-women-andmicrofinance-in-south-india-apr-2008.pdf

10. Menon PP, Priya V. Impact of Market Economic Principles on Workplace Anxiety and Stress. Indian J Public Heal Res Dev. 2019;10(9):145.

11. Kanagaraj S, Priya V, Gayathri K. Influence of Poverty on Health among Tribes in Nilgiris District, Tamilnadu: Pattern of Diseases and Health Care Practices. Indian J Public Heal Res Dev. 2019;10(9):77.

12. Kanagaraj E, Ralte S. Social mobilisation and tribal development: Dynamics and impact of self-help groups in Mizoram. In: Behera MC, Parida RC, Baruah D, editors. Development dynamics : finance, empowerment and entrepreneurship [Internet]. DVS Publishers; 2012 [cited 2019 May 10]. p. 260. Available from: https://www.researchgate.net/ publication/286441529_Social_Mobilisation_and Tribal_Development_Dynamics_and_Impact_of_Self-help_Groups_in_Mizoram

13. Kumar N, Raghunathan K, Arrieta A, Jilani A, Chakrabarti S, Menon P, et al. Social networks, mobility, and political participation: The potential for women's self-help groups to improve access and use of public entitlement schemes in India. World Dev [Internet]. 2019;114:28-41. Available from: https://doi.org/10.1016/j.worlddev.2018.09.023

14. Channell K. The Social Mobilization Approach: A Participatory Model for Local Resource Mobilization. Can J Dev Stud Can d'études du développement. 2011;21(sup1):479-93.

15. Brody C, de Hoop T, Vojtkova M, Warnock R, Dunbar M, Murthy P, et al. Can self-help group programs improve women's empowerment? A systematic review. J Dev Eff [Internet]. 2017;9(1):15-40. Available from: http://dx.doi.org /10.1080/19439342.2016.1206607

16. Finnis E. Collective Action, Envisioning the Future and Women's Self-help Groups: A Case Study from South India. Indian J Gend Stud. 2017;24(1):1-23.

17. Mokta M. Empowerment Of Women In India: A Critical Analysis. Indian J Public Adm [Internet]. 2014 [cited 2019 Apr 30];3(July-September). Available from: http://www.iipa.org.in/New Folder/8--Mamta.pdf

18. Nair A. Sustainability of Microfinance Self Help Groups in India: Would Federating Help? [Internet]. The World Bank; 2005 [cited 2019 May 9]. (Policy Research Working Papers). Available from: http:// elibrary.worldbank.org/doi/book/10.1596/18139450-3516

19. Das T, Guha P. Measuring Women's Self-help Group Sustainability: A Study of Rural Assam. Int J Rural Manag [Internet]. 2019 Apr 7 [cited 2019 May 8];15(1):116-36. Available from: http://journals. sagepub.com/doi/10.1177/0973005219836040

20. Moyle TL, Dollard M, Biswas SN. Personal and economic empowerment in rural indian women: A self-help group approach. Int J Rural Manag. 2006;2(2):245-66. 